\title{
PENGARUH MODEL PEMBELAJARAN PROBING PROMPTING BERBANTUAN MEDIA VIDEO TERHADAP HASIL BELAJAR IPA
}

\author{
Ni Wayan Sri Kartika Dewi ${ }^{1}$, Desak Putu Parmiti ${ }^{2}$, I Gusti Ngurah Japa ${ }^{3}$ \\ 11.2.3 Jurusan Pendidikan Guru Sekolah Dasar, FIP, Universitas Pendidikan Ganesha \\ Singaraja, Indonesia \\ e-mail: srikartikadewi393@gmail.com ${ }^{1}$, dskpt parmiti@yahoo.co.id ${ }^{2}$, ngriapa pgsd@yahoo.id $^{3}$
}

\begin{abstract}
ABSTRAK
Penelitian ini bertujuan untuk mengetahui pengaruh yang signifikan model pembelajaran probing-prompting berbantuan media video terhadap hasil belajar IPA siswa kelas V SD di gugus V Kecamatan Bangli Tahun Ajaran 2018.Penelitian ini adalah penelitian semu (quasi eksperimen),denganrancangan nonequivalent posttest only control group design. Populasi penelitian ini adalah seluruh kelas V SD di Gugus V Kecamatan Bangli. Sampel penelitian ini adalah kelas V SDN 3 Kayubihi dan SDN 1 Landih. Sampel ditentukan menggunakan teknik random sampling. Data hasil belajar dikumpulkan menggunakan tes pilihan ganda. Data yang diperoleh dianalisis menggunakan teknik analisis statistik deskriptif dan analisis statistik inferensial (uji-t). Hasil penelitian menunjukkan bahwa terdapat perbedaan hasil belajar IPA antara kelompok siswa yang dibelajarkan menggunakan model pembelajaran Probing-prompting berbantuan media video dan kelompok siswa yang dibelajarkan menggunakan model pembelajaran konvensional pada siswa kelas V SD di Gugus $V$ Kecamatan Bangli. Hal ini ditunjukkan oleh $t_{\text {hitung }}(5,051)>t_{\text {tabel }}(2,002)$. Selanjutnya, rata-rata (mean) kelompok eksperimen $(18,00)$ lebih besar daripada rata-rata (mean) kelompok kontrol $(13,00)$. Dengan demikian, model pembelajaran Probing-prompting berbantuan media videoberpengaruh secara signifikan terhadap hasil belajar IPA siswa kelas V SD di Gugus V Kecamatan Bangli. Maka model pembelajaran probing-prompting dapat diterapkan sebagai salah satu model yang inovatif dalam pembelajaran IPA di SD.
\end{abstract}

Kata Kunci : probing-prompting,video,hasil belajar

\begin{abstract}
This researchaims to know the significant effect of learning media by using video assisted probing prompting on the results of science learning on fifth grade of elementary school on five cluster of Bangli Sub-district in academic year 2018. This study is a quasi experiment, with non-equivalent posttest, only control group design. The population of this study was all of the fifth grade classes of SD in Group V Bangli District. The samples of this study were the fifth classes of SDN 3 Kayubihi and SDN 1 Landih. The samples were determined using random sampling technique. Learning outcome data were collected by using multiple-choice test. The data obtained were analyzed using descriptive statistical analysis technique and inferential statistical analysis (t-test). The results showed that there were differences in the learning outcomes of the science between the students who were taught using the Probing-prompting-assisted learning model assisted by video and students who were taught using conventional learning model in the fifth grade of elementary students in Group $V$ Bangli District. This was shown by $t_{\text {count }}(5,051)>t_{\text {table }}(2,002)$. Furthermore, the mean of experimental group $(18.00)$ is bigger than the control group's mean (13.00). Thus, the Probing-prompting learning model assisted by video has positive effect on the students science learning outcomes of the fifth grade of elementary school in Group V of Bangli District. So, the probing prompting learning model can be applied as one of the innovative model in learning science for elementary school.
\end{abstract}

Keywords : probing-prompting, videos, learning results

Indonesian Journal Of Educational Research and Review | 229 


\section{Pendahuluan}

IPA merupakan ilmu pengetahuan mempunyai kedudukan yang sangat penting dalam kehidupan sehari-hari maupun dalam perkembangan ilmu pengetahuan dan teknologi. Perkembangan ilmu pengetahuan dan teknologi tidak lepas dari dukungan dan peranan IPA. Pelajaran IPA di sekolah dasar tergolong pembelajaran yang sangat menyenangkan, pembelajaran IPA yang mempelajari tentang gejala-gejala alam atau fenomena alam yang ada disekitar lingkungan tentunya sangat menarik untuk dipelajari. Ariasih(2014) menyatakan bahwa "pada dasarnya sains atau IPA adalah ilmu pengetahuan yang bidang sasarannya adalah alam semesta". "Pembelajaran IPA di SD hendaknya membuka kesempatan untuk memupuk rasa ingin tahu peserta didik secara alamiah" (Beniasih, 2015). Menurut Rustina (2014) menyatakan bahwa, "dalam proses pembelajaran IPA ada yang perlu diperhatikan antara lain adalah model atau metode pembelajaran".

Untuk menguasai dan mencipta teknologi di masa depan diperlukan penguasaan IImu Pengetahuan Alam (IPA) yang kuat sejak dini. Penguasaan IPA sejak dini bisa dimulai saat anak berada di sekolah dasar. Hal ini sebagaimana dimaksud Undang-Undang No. 20 Tahun 2003 tentang Sistem Pendidikan Nasional (pasal 17 ayat 1) menyebutkan bahwa "Pendidikan dasar merupakan jenjang pendidikan yang melandasi jenjang pendidikan menengah". Untuk itu IPA sejak dini harus dipahami dengan baik dan benar, karena konsep-konsep dalam IPA merupakan suatu rangkaian konsep yang menimbulkan hubungan sebab akibat, sehingga pemahaman yang salah terhadap suatu konsep akan mengakibatkan pada kesalahan pemahaman yang salah terhadap suatu konsep akan berakibat pada kesalahan pemahaman terhadap konsep-konsep selanjutnya.

Peranan IPA yang begitu besar ternyata tidak sesuai dengan kualitas proses dan hasil pembelajaran IPA siswa khususnya di sekolah dasar. Kebanyakan siswa menganggap IPA sulit dipelajari dan di pahami. Menurut Winaputra (1992:122) menyatakan "IPA merupakan ilmu yang berhubungan dengan gejala alam dan kebendaan yang sistematis dan tersusun secara teratur, dan dapat juga diartikan pengetahuan itu tersusun dalam suatu sistem, tidak berdiri sendiri, satu dengan yang lainnya saling berkaitan". Hal itu sejalan dengan fakta yang ada dilapangan bahwa para siswa mengalami kesulitan dalam belajar terutama IPA. Hal ini merupakan tantangan bagi guru untuk menjadikan proses pembelajaran IPA menarik, mudah dipahami siswa, dan menumbuhkan proses berfikir kritis siswa yang bermuara pada meningkatnya hasil belajar siswa. Tugas dan peran guru dalam proses pembelajaran tidak hanya sebagai pemberi informasi, tetapi juga sebagai fasilitator dan motivator bagi siswa agar siswa dapat mengkonstruksi sendiri pengetahuannya melalui berbagai aktivitas yang menuntut peran aktif siswa dalam pembelajaran.

Namun pada kenyataannya proses pembelajaran IPA di sekolah dasar menunjukkan bahwa kegiatan pemecahan masalah dalam proses pembelajaran IPA disekolah dasar belum dijadikan sebagai kegiatan utama. Berdasarkan observasi awal yang telah dilakukan pada tanggal 25 November 2017 dengan guru atau wali yang mengampu mata pelajaran IPA di kelas V SD di Gugus V Kecamatan Bangli, diperoleh keterangan bahwa dalam proses pembelajaran mata pelajaran IPA guru masih menekankan pada keterampilan mengerjakan soal dan tidak melakukan praktikum. Guru hanya menggunakan metode ceramah dari pada memberikan kesempatan kepada siswa untuk menemukan sendiri konsep-konsep yang dipelajari. Siswa cenderung pasif dan hanya mencatat, mendengarkan sesuai perintah guru tanpa berupaya untuk menemukan sendiri konsep-konsep yang dipelajari. Pembelajaran menjadi berpusat pada guru sedangkan siswa menjadi pasif karena hanya menunggu rangsangan dari guru.

$\mathrm{Hal}$ demikin didukung dengan hasil wawancara yang telah dilakukandi Gugus $\mathrm{V}$ Kecamatan Bangli. Adapun hasil wawancara tersebut adalah sebagai berikut 1) banyaknya pendidik masih menerapkan model yang monoton, sehingga pembelajaran menjadi kurang aktif, 2) di dalam proses pembelajaran di SD Gugus V Kecamatan Bangli, khususnya pada mata pelajaran IPA masih sangat kurang dikarenakan pembelajaran yang kurang menarik dan pembelajaran masih berpusat pada guru, sehingga keaktifan belajar siswa tidak tercapai 
dengan maksimal, 3) kurangnya penggunaan model, media, maupun metode pembelajaran di dalam proses pembelajaran.

Berdasarkan wawancara yang dilakukan di seluruh SD Gugus V Kecamatan Bangli, adapun studi dokumen yang ditemukan pada pembelajaran IPA masih banyaknya siswa yang mendapatkan nilai dibawah KKM. Data tersebut bisa dilihat pada tabel 1.1.

Tabel 1. Nilai Data UTS di SD Gugus V Kecamatan Bangli

\begin{tabular}{cccccc}
\hline No & $\begin{array}{c}\text { SD di Gugus V } \\
\text { Kecamatan Bangli }\end{array}$ & $\begin{array}{c}\text { Jumlah } \\
\text { Siswa }\end{array}$ & KKM & $\begin{array}{c}\text { Persentase Ketuntasan } \\
\text { Tuntas } \\
(\%)\end{array}$ & $\begin{array}{c}\text { Belum tuntas } \\
(\%)\end{array}$ \\
\hline 1 & SDN 2 Kayubihi & 10 & 70 & 20 & 80 \\
2 & SDN 3 Kayubihi & 36 & 75 & 28 & 72 \\
3 & SDN 1 Landih & 24 & 75 & 33 & 67 \\
4 & SDN 2 Landih & 18 & 65 & 28 & 72 \\
5 & SDN 1 Pengotan & 30 & 71 & 33 & 67 \\
6 & SDN 2 Pengotan & 27 & 70 & 30 & 70 \\
7 & SDN 3 Pengotan & 21 & 75 & 24 & 76 \\
\hline
\end{tabular}

Berdasarkan Tabel 1 banyak siswa yang mendapatkan nilai dibawah KKM dari 166 siswa, siswa yang belum tuntas lebih banyak daripada siswa yang sudah tuntas. Dilihat dari data tersebut hal demikian perlu ditangani dengan cepat.

Adanya permasalahan tersebut menyebabkan perlunya sebuah usaha perbaikan atau tindakan untuk mengatasi permasalahan tersebut. Salah satu upaya yang dapat dilakukan untuk meningkatkan hasil belajar IPA adalah dengan menggunakan model pembelajaran. Model pembelajaran yang memiliki karakteristik memberikan kesempatan kepada siswa untuk membangun pengetahuan berdasarkan pengalaman nyata, sehingga dapat meningkatkan hasil belajar. Salah satu model pembelajaran yang dapat dijadikan solusi adalah model pembelajaran probing-prompting.

Model pembelajaran probing-prompting dapat memudahkan siswa mengakomudasi dan membangun pengetahuannya sendiri. Hal ini dikarenakan siswa dapat mengontruksi sendiri konsep, prinsip, dan aturan menjadi pengetahuan baru. Dalam penerapan model pembelajaran probing-prompting proses tanya jawab dilakukan dengan menunjuk siswa secara acak sehingga setiap siswa mau tidak mau harus berpartisipasi aktif, siswa tidak bisa menghindar dari proses pembelajaran, setiap saat ia bisa dilibatkan dalam proses tanya jawab. Selain itu siswa harus fokus pada penyelesaian masalah atau pertanyaan yang memandu mereka memahami konsep dan prinsip yang terkait dengan proyek praktikum.

Penerapan model pembelajaran probing-prompting untuk meningkatkan hasil belajar dalam mata pelajaran IPA dapat dibantu dengan media video pembelajaran. Media video pembelajaran merupakan jenis media audio visual yang menyajikan pesan pembelajaran baik yang berisi konsep, prinsip, prosedur, teori aplikasi pengetahuan untuk membantu pemahaman terhadap suatu materi pembelajaran dalam bentuk gambar dan suara. Dengan menggunakan model probing-prompting berbantuan media video akan dapat memberikan kesan yang menyenangkan untuk para siswa, selain itu dapat meningkatkan hasil belajar IPA pada siswa kelas V SD di Gugus V Kecamatan Bangli.

Berdasarkan uraian diatas, pengaruh model pembelajaran probing- prompting berbantuan media video masih harus di teliti. Untuk itu, dalam penelitian ini mengangkat judul "Pengaruh Model Pembelajaran Probing Prompting Berbantuan Media Video Terhadap Hasil Belajar IPA Siswa Kelas V SD di Gugus V Kecamatan Bangli Tahun Ajaran 2018".

Swarjawa (2013) "probing-prompting adalah suatu model pembelajaran yang berpusat pada siswa (student centered)". Model pembelajaran ini sesuai dengan paham konstruktivis yang memberikan keleluasan pada peserta didik untuk aktif mengkonstruksi pengetahuan 
sendiri. Menurut Shoimin (2014:126) menyatakan bahwa "teknik probing-prompting adalah pembelajaran dengan cara guru menyajikan serangkaian pertanyaan yang sifatnya menuntun dan menggali sehingga terjadi proses berfikir yang mengaitkan pengetahuan dan pengalaman siswa dengan pengetahuan baru yang sedang dipelajari".

Dengan model pembelajaran ini, proses tanya jawab dilakukan dengan menunjuk siswa secara acak sehingga setiap siswa mau tidak mau harus berpartisipasi aktif, siswa tidak bisa menghindar dari proses pembelajaran, setiap saat ia bisa dilibatkan dalam proses tanya jawab. Kemungkinan akan terjadi suasana tegang, tetapi bisa dibiasakan. Untuk mengurangi kondisi tegang, guru hendaknya mengajukan serangkaian pertanyaan disertai dengan wajah ramah, suara menyejukkan, dan nada yang lembut. Ada canda, senyum, dan tertawasehingga suasana menjadi nyaman, menyenangkan, dan ceria. Jangan lupa jawaban siswa yang salah harus dihargai karena salah adalah ciri bahwa dia sedang belajar dan telah berpartisipasi.

Berdasarkan hasil penelitianyang dilakukan oleh Susanti (2017), disimpulkan bahwa keaktifan guru menurun, sedangkan keaktifan siswa dan kemampuan berpikir kritis matematis siswa meningkat dengan menggunakan model pembelajaran probing-prompting dalam pembelajaran matematika khususnya pada pokok bahasan Turunan Fungsi Aljabar. Terbukti dari hasil penelitian dengan tindakan model pembelajaran probing-prompting dapat meningkatkan kemampuan berpikir kritis matematis siswa. Oleh karena itu diharapkan kepada guru matematika juga dapat menerapkan model pembelajaran probing-prompting untuk meningkatkan kemampuan berpikir dengan materi pembelajaran yang karakteristiknya sama.

Berdasarkan gambaran hasil analisis data yang diperoleh selama penelitian, dapat diambil simpulan secara umum bahwa pembelajaran dengan menerapkan Model Pembelajaran Cooperative tipe Probing Prompting di SDN ISOLA Bandung pada pelajaran IPA kelas V dapat meningkatkan kemampuan berpikir kreatif siswa, Amir (2017).

Model pembelajaran Probing Prompting memiliki langkah-langkah dalam proses pembelajarannya, pada langkah tersebut guru dapat melihat keaktifan siswa saat proses pembelajaran serta dapat memperhitungkan apa yang harus dilakukan yaitu: 1) guru menghadapkan siswa pada situasi baru, misalkan dengan memerhatikan gambar, rumus, atau situasi lainnya yang mengandung permasalahan, 2) menungngu beberapa saat untuk memberikan kesempatan kepada siswa untuk merumuskan jawaban yang melakukan diskusi kecil dalam merumuskannya, 3) guru mengajukan persoalan kepada siswa yang sesuai dengan tujuan pembelajaran khusus (TPK) atau indikator kepada seluruh siswa, 4) menunggu beberapa saat untuk memberikan kesempatan kepada siswa untuk merumuskan jawaban atau melakuakan diskusi kecil dalam merumuskannya, 5) menunjuk salah satu siswa untuk menjawab pertanyaan, 6) jika jawabannya tepat, guru meminta tanggapan kepada siswa lain tentang jawaban tersebut untuk meyakinkan bahwa seluruh siswa terlibat dalam kegiatan yang sedang berlangsung. Namun, jika siswa tersebut mengalami kemacetan jawaban, dalam hal ini jawaban yang diberikan kurang tepat, tidak tepat, atau diam, guru mengajukan pertanyaanpertanyaan lain yang jawabannya merupakan petunjuk jalan penyelesaian jawaban. Lalu dilanjutkan dengan pertanyaan yang menuntut siswa berfikir pada tingkat yang lebih tinggi, sampai dapat menjawab pertanyaan sesuai dengan kompetensi dasar atau indikator. Pertanyaan yang dilakukan pada langkah keenam ini sebaikknya diajukan pada beberapa siswa yang berbeda agar seluruh siswa terlibat dalam seluruh kegiatan probing-prompting, 7) guru mengajukan pertanyaan diakhir pada siswa yang berbeda untuk lebih menekankan bahwa indikatortersebut benar-benar telah dipahami oleh seluruh siswa.

\section{Metode}

Jenis penelitian yang dipilih adalah penelitian eksperimen semu (quasi eksperimen), karena tidak semua variabel yang muncul dan kondisi eksperimen dapat diatur secara ketat. Dalam penelitian ini subjek penelitian diberikan perlakuan menggunakan model pembelajaran probing-prompting dan model pembelajaran konvensional terhadap hasil belajar IPA.

Dalam rancangan penelitian ini adalah post-test only control group designe. Penelitian dengan desain post-test only control group designe, adalah penelitian terdapat dua kelompok 
yang masing-masing dipilih dengan cara random, kelompok pertama diberi perlakuan dan kelompok yang lain tidak diberi perlakuan (Sugiyono, 2008).

Menurut Sugiyono (2008:117) menyatakan bahwa, populasi adalah "wilayah generalisasi yang terdiri atas objek/subjek yang mempunyai kualitas dan karakteristik tertentu yang diterapkan untuk mempelajari dan kemudian ditarik kesimpulannya". Populasi penelitian ini adalah seluruh siswa kelas V di SD Gugus V Kecamatan Bangli yang berjumlah 166 siswa. Menurut Agung (2014:69) menyatakan bahwa "sampel adalah sebagian dari populasi yang diambil, yang dianggap mewakili seluruh populasi dan diambil dengan menggunakan teknik tertentu". Sampel merupakan bagian dari jumlah dan karakteristik tertentu yang dimiliki oleh suatu populasi (Sugiyono, 2006). Jadi dapat disimpulkan bahwa sampel adalah sebagian dari anggota populasi yang dapat mewakili populasi. Pengambilan sampel menggunakan teknik random sampling yaitu simple random sampling dengan cara undian. Penarikan sampel sederhana ini nantinya akan membuat semua subjek mendapat hak yang sama untuk memperoleh kesempatan dipilih menjadi anggota sampel (Agung, 2014). Maka dalam hal ini ketujuh sekolah yang setara selanjutnya diundi untuk menentukan dua sekolah sebagai sampel. Setelah mengetahui kedua kelompok sampel, selanjutnya dilakukan pengundian untuk menentukan dua sekolah sebagai sampel. Setelah mengetahui kedua kelompok sampel, selanjutnya dilakukan pengundian untuk menentukan kelas eksperimen dan kontrol. Hasil pengundian tersebut yaitu SDN 3 Kayubihi sebagai kelompok eksperimen dan SDN 1 Landih sebagai kelompok kontrol. Berdasarkan teknik tersebut SD Negeri 3 Kayubihi mendapatkan perlakuan pembelajaran dengan menggunakan model pembelajaran probing-prompting, sedangkan SD Negeri 1 Landih tidak mendapatkan perlakuan. Dalam melakukan sebuah penelitian, metode pengumpulan data dalam penelitian ini menggunakan metode tes. Tes yang dilakukan dalam penelitian yaitu untuk mengetahui hasil belajar IPA siswa kelas V. Instrumen pengumpulan data merupakan alat-alat yang digunakan untuk mengumpulkan data dalam penelitian. Instrumen yang digunakan dalam penelitian ini adalah tes hasil belajar IPA dengan bentuk tes objektif pilihan ganda.Tes pilihan ganda ini mengungkapkan tentang penguasaan siswa terhadap pelajaran IPA yang mereka peroleh di kelas. Tes yang telah disusun kemudian diujicobakan untuk mendapatkan gambaran tentang kelayakan tes tersebut. Tes yang telah diuji cobakan kemudian dianalisis untuk menentukan validitas isi, uji tingkat kesukaran, uji daya beda, uji reliabilitas.

Setelah diperoleh hasil dari uji prasyarat analisis data, dilanjutkan dengan pengujian hipotesis penelitian $\left(\mathrm{H}_{1}\right)$ dan hipotesis nol $\left(\mathrm{H}_{0}\right)$. Pengujian hipotesis tersebut dilakukan dengan menggunakan uji-t sampel independent (tidak berkorelasi) dengan rumus polled varians dengan kriteria $\mathrm{H}_{0}$ ditolak jika $t_{\text {hitung }}>t_{\text {tabel }}$ dan $\mathrm{H}_{0}$ diterima jika $t_{\text {hitung }}<t_{\text {tabel }}$.

Uji hipotesis menggunakan rumus polled varians karena data hasil belajar IPA siswa kelompok eksperimen dan kontrol adalah normal dan homogen. Dari hasil perhitungan yang dilakukan, diperoleh $t_{\text {hitung }}=5,051$, sedangkan $t_{\text {tabel }}=2,002$ pada taraf signifikansi $5 \%$ dengan $\mathrm{db}=58$. Hal ini berarti $t_{\text {hitung }}>\mathrm{t}_{\text {tabel }}$ sehingga $\mathrm{H}_{0}$ ditolak dan $\mathrm{H}_{1}$ diterima. Berikut ringkasan uji hipotesis dideskripsikan seperti pada tabel 2 di bawah ini.

Tabel 2. Ringkasan Hasil Uji Hipotesis

\begin{tabular}{clllllll}
\hline Data & Kelompok & Varians & $\mathbf{N}$ & $\mathbf{D b}$ & $\mathbf{t}_{\text {hitung }}$ & $\mathbf{t}_{\text {tabel }}$ & Kesimpulan \\
\hline Hasil Belajar & Eksperimen & $\begin{array}{l}17,54 \\
8,90\end{array}$ & 28 & \multirow{2}{*}{58} & \multirow{2}{*}{5,051} & \multirow{2}{*}{2,002} & $\begin{array}{l}t_{\text {hitung }}>t_{\text {tabel }} \mathrm{H}_{0} \\
\text { ditolak }\end{array}$ \\
& Kontrol & 8,90 & & & & dial
\end{tabular}

Berdasarkan hasil perhitungan uji-t, diperoleh $t_{\text {hitung }}$ sebesar 5,051. Sedangkan $t_{\text {tabel }}$ dengan $\mathrm{db}=58$, dan taraf signifikansi $5 \%$ adalah 2,002. Ini berarti $t_{\text {hitung }}$ lebih besar dari $t_{\text {tabel }}$ ( $\left.t_{\text {hitung }}>t_{\text {tabel }}\right)$, sehingga $\mathrm{H}_{0}$ ditolak dan $\mathrm{H}_{1}$ diterima. Dengan demikian, dapat dinyatakan bahwa terdapat perbedaan hasil belajar IPA antara kelompok siswa yang mengikuti pembelajaran dengan model Probing-prompting dan kelompok siswa yang mengikuti pembelajaran model konvensional. 
Tabel 3. Distribusi Frekuensi Hasil Belajar Kelompok Eksperimen

\begin{tabular}{lllllll}
\hline $\begin{array}{l}\text { Kelas } \\
\text { Interval }\end{array}$ & & $\begin{array}{l}\text { Titik } \\
\text { Tengah (X) }\end{array}$ & $\begin{array}{l}\text { Frekuensi } \\
\text { Absolut (f) }\end{array}$ & $\begin{array}{l}\text { Frekuensi } \\
\text { Komulatif } \\
\text { (fk) }\end{array}$ & fX & $\begin{array}{l}\text { Frekuensi } \\
\text { Relatif (\%) }\end{array}$ \\
\hline 10 & 12 & 11 & 5 & 5 & 55 & 13.89 \\
13 & 15 & 14 & 5 & 10 & 70 & 13.89 \\
16 & 18 & 17 & 6 & 16 & 102 & 16.67 \\
19 & 21 & 20 & 15 & 31 & 300 & 41.67 \\
22 & 24 & 23 & 3 & 34 & 69 & 8.33 \\
25 & 27 & 26 & 2 & 36 & 52 & 5.56 \\
& Total & & 36 & & $\mathbf{6 4 8}$ & $\mathbf{1 0 0 . 0 0}$ \\
\hline
\end{tabular}

Berdasarkan uraian di atas, dapat dideskripsikan mean (M), median (Md), modus (Mo), dan standar deviasi $(S D)$, yaitu modus $(M o)=19,79$, median $(M d)=18,90$, mean $(M)=18,00$, varians $\left(s^{2}\right)=17,54$, dan standar deviasi $(S D)=4,19$.

Agar dapat diamatai dan dipahami tentang sebaran nilai modus, median, mean, , varias, dan standar devisiasi dapat ditunjukkan pada grafik poligon seperti pada gambar 1.di bawah ini.

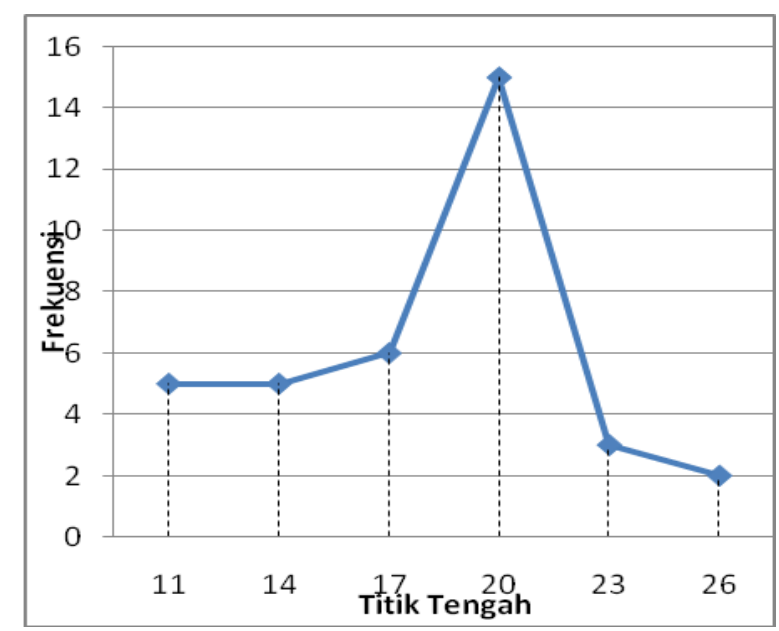

Gambar 1. Kurva Juling Polygon Negatif

Skor Modus (Mo), Median (Md), Mean (M), yang digambarkan dalam grafik poligon tampak bahwa kurva sebaran data kelompok siswa yang mengikuti model pembelajaran Probing-prompting merupakan juling negatif karena $M o>M d>M(19,79>18,90>18,00)$. Hasilnya menunjukkan bahwa sebagian besar skor siswa kelompok eksperimen cenderung tinggi.

Tabel 4. Distribusi Frekuensi Hasil Belajar Kelompok Kontrol

\begin{tabular}{|c|c|c|c|c|c|c|}
\hline \multicolumn{2}{|c|}{ Kelas Interval } & $\begin{array}{l}\text { Titik Tengah } \\
(\mathrm{X})\end{array}$ & $\begin{array}{l}\text { Frekuensi } \\
\text { Absolut (f) }\end{array}$ & $\begin{array}{l}\text { Frekuensi } \\
\text { Komulatif (fk) }\end{array}$ & $f X$ & $\begin{array}{l}\text { Frekuensi } \\
\text { Relatif (\%) } \\
\end{array}$ \\
\hline 8 & 9 & 8.5 & 2 & 2 & 17 & 8.33 \\
\hline 10 & - $\quad 11$ & 10.5 & 5 & 7 & 52.5 & 20.83 \\
\hline 12 & - $\quad 13$ & 12.5 & 9 & 16 & 112.5 & 37.50 \\
\hline 14 & $-\quad 15$ & 14.5 & 3 & 19 & 43.5 & 12.50 \\
\hline 16 & $-\quad 17$ & 16.5 & 3 & 22 & 49.5 & 12.50 \\
\hline
\end{tabular}




\begin{tabular}{|c|c|c|c|c|c|c|}
\hline 18 & $\begin{array}{l}-19 \\
\end{array}$ & 18.5 & 2 & 24 & 37 & 8.33 \\
\hline Total & & & 24 & & 312 & 100.00 \\
\hline
\end{tabular}

Berdasarkan uraian di atas, dapat dideskripsikan modus (Mo), median (Md), mean (M), dan standar deviasi $(S D)$, yaitu modus $(M o)=12,30$, median $(M d)=12,61$, mean $(M)=13,00$, varians $=8,90$, dan standar deviasi $(S D)=2,98$. Adapun perhitungan secara lengkap tentang hasil belajar IPA kelompok kontrol dapat dilihat pada lampiran 19.

Agar dapat diamatai dan dipahami tentang sebaran nilai mean, median, modus, varias, dan standar devisiasi dapat ditunjukkan pada grafik poligon seperti pada gambar 2.di bawah ini.

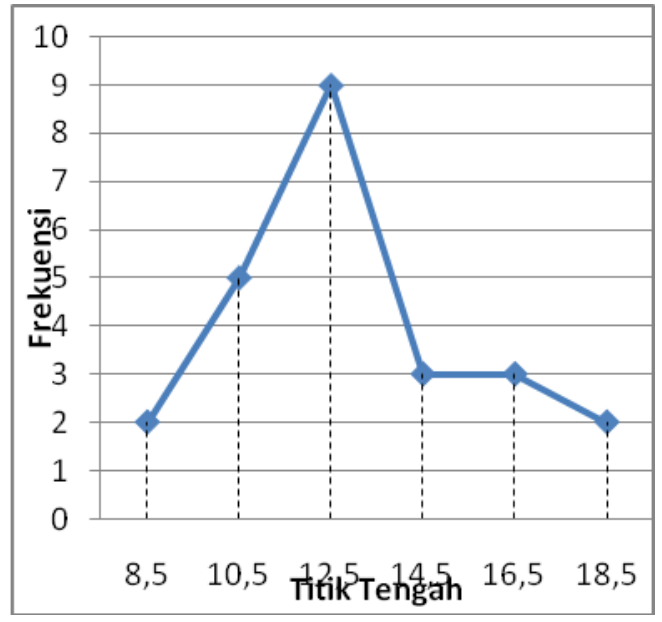

Gambar 2. Kurva Polygon Juling Positif

Skor Modus (Mo), Median (Me), Mean (M), yang digambarkan dalam grafik poligon tampak bahwa kurva sebaran data kelompok siswa yang mengikuti model pembelajaran konvensional merupakan juling positif karena $M o<M e<M \quad(12,30<12,61<13,00)$. Hasilnya menunjukkan bahwa sebagian besar skor siswa kelompok kontrol cukup.

Uji normalitas sebaran data dilakukan untuk membuktikan bahwa frekuensi data hasil penelitian benar-benar berdistribusi normal. Uji normalitas sebaran data dilakukan terhadap hasil post-test kelompok eksperimen dan kelompok kontrol.

Berdasarkan analisis data yang dilakukan, dapat disajikan hasil uji normalitas sebaran data hasil belajar IPA siswa kelompok eksperimen dan kontrol.

Tabel 5. Hasil Uji Normalitas Sebaran Data Hasil Belajar IPA

\begin{tabular}{|c|c|c|c|c|c|c|}
\hline No. & $\begin{array}{l}\text { Kelompok } \\
\text { Belajar }\end{array}$ & Data & Hasil & $\chi^{2}$ & $\begin{array}{l}\text { Nilai Kritis dengan Taraf } \\
\text { Signifikansi } 5 \%\end{array}$ & Status \\
\hline 1. & Eksperimen & & & 8,99 & 11,07 & Normal \\
\hline 2. & Kontrol & & & 7.25 & 11.07 & Normal \\
\hline
\end{tabular}

Kriteria pengujian, jika $\chi^{2}{ }_{\text {hitung }}<\chi^{2}{ }_{\text {tabel }}$ dengan taraf signifikasi $5 \%$ (dk $=$ jumlah kelas dikurangi parameter, dikurangi 1), maka data berdistribusi normal. Sedangkan, jika $\chi_{\text {hitung }}^{2} \geq \chi^{2}$ tabel , maka data tidak berdistribusi normal.

Berdasarkan hasil perhitungan dengan menggunakan rumus chi-kuadrat, diperoleh $\chi^{2}$ hitung hasil belajar IPA siswa kelompok eksperimen adalah 8,99 dan $\chi^{2}$ tabel dengan taraf signifikansi $5 \%$ dan $\mathrm{dk}=5$ adalah 11,07 . Ini berarti, $\chi^{2}$ hitung hasil belajar IPA siswa kelompok 
eksperimen lebih kecil dari $\chi^{2}{ }_{\text {tabel }}\left(\chi^{2}{ }_{\text {hitung }}<\chi^{2}{ }_{\text {tabel }}\right)$, sehingga data hasil belajar IPA siswa kelompok eksperimen berdistribusi normal. Sedangkan, $\chi^{2}$ hitung hasil belajar IPA siswa kelompok kontrol adalah 7,25dan $\chi^{2}$ tabel dengan taraf signifikansi $5 \%$ dan $\mathrm{dk}=5$ adalah 11,07. Ini berarti, $\chi^{2}$ hitung hasil post-test kelompok kontrol lebih kecil dari $\chi_{\text {tabel }}^{2} \chi_{\text {hitung }}^{2}<\chi^{2}{ }_{\text {tabel }}$ ), sehingga data hasil belajar IPA siswa kelompok kontrol dapat dikatakan berdistribusi normal.

Uji homogenitas dilakukan terhadap varians pasangan antar kelompok eksperimen dan kontrol. Uji yang digunakan adalah uji-F dengan kriteria data homogen jika $F_{\text {hitung }}<F_{\text {tabel }}$. Rangkuman hasil uji homogenitas varians antar kelompok eksperimen dan kontrol dapat dideskripsikan seperti pada tabel 6.di bawah ini.

Tabel 6. Hasil Uji Homogenitas Kelompok Eksperimen dan Kontrol

\begin{tabular}{|c|c|c|c|}
\hline $\begin{array}{l}\text { Kelompok Data } \\
\text { Hasil Belajar }\end{array}$ & F-hitung & $\begin{array}{c}\text { F-tabel dengan } \\
\text { Taraf Signifikansi } 5 \%\end{array}$ & Status \\
\hline $\begin{array}{l}\text { Eksperimen } \\
\text { Kontrol }\end{array}$ & 1,97 & 4,01 & Homogen \\
\hline
\end{tabular}

Berdasarkan Tabel 6 di atas, diketahui $F_{\text {hitung }}$ hasil belajar IPA siswa kelompok eksperimen dan kontrol adalah 1,97. Sedangkan $F_{\text {tabel }}$ dengan $\mathrm{db}_{\text {pembilang }}=35, \mathrm{db}_{\text {penyebut }}=23$, dan taraf signifikansi $5 \%$ adalah 4,01. Ini berarti, varians data hasil belajar IPA siswa kelompok eksperimen dan kontrol adalah homogen.

Berdasarkan uji prasyarat analisis data, diperoleh bahwa data hasil belajar IPA siswa kelompok eksperimen dan kontrol adalah normal dan homogen. Setelah diperoleh hasil dari uji prasyarat analisis data, dilanjutkan dengan pengujian hipotesis penelitian $\left(\mathrm{H}_{1}\right)$ dan hipotesis nol $\left(\mathrm{H}_{0}\right)$. Pengujian hipotesis tersebut dilakukan dengan menggunakan uji-t sampel independent (tidak berkorelasi) dengan rumus polled varians dengan kriteria $\mathrm{H}_{0}$ ditolak jika $t_{\text {hitung }}>\mathrm{t}_{\text {tabel }}$ dan $\mathrm{H}_{0}$ diterima jika $\mathrm{t}_{\text {hitung }}<\mathrm{t}_{\text {tabel }}$.

Uji hipotesis menggunakan rumus polled varians karena data hasil belajar IPA siswa kelompok eksperimen dan kontrol adalah normal dan homogen. Dari hasil perhitungan yang dilakukan, diperoleh $t_{\text {hitung }}=5,051$, sedangkan $t_{\text {tabel }}=2,002$ pada taraf signifikansi $5 \%$ dengan $\mathrm{db}=58$. Hal ini berarti $t_{\text {hitung }}>\mathrm{t}_{\text {tabel }}$ sehingga $\mathrm{H}_{0}$ ditolak dan $\mathrm{H}_{1}$ diterima. Berikut ringkasan uji hipotesis dideskripsikan seperti pada tabel 7.di bawah ini.

Tabel 7. Ringkasan Hasil Uji Hipotesis

\begin{tabular}{clllllll}
\hline Data & Kelompok & Varians & $\mathbf{N}$ & $\mathbf{D b}$ & $\mathbf{t}_{\text {hitung }}$ & $\mathbf{t}_{\text {tabel }}$ & \multicolumn{2}{c}{ Kesimpulan } \\
\hline Hasil Belajar & Eksperimen & 17,54 & 28 & \multirow{2}{*}{58} & 5,051 & 2,002 & $\begin{array}{l}t_{\text {hitung }}>t_{\text {tabel }} \mathrm{H}_{0} \\
\end{array}$ \\
& Kontrolak & 8,90 & 29 & & & & ditolak \\
\hline
\end{tabular}

Berdasarkan hasil perhitungan uji-t, diperoleh $t_{\text {hitung }}$ sebesar 5,051. Sedangkan $t_{\text {tabel }}$ dengan $\mathrm{db}=58$, dan taraf signifikansi $5 \%$ adalah 2,002. Ini berarti $t_{\text {hitung }}$ lebih besar dari $t_{\text {tabel }}$ (thitung $>t_{\text {tabel }}$ ), sehingga $\mathrm{H}_{0}$ ditolak dan $\mathrm{H}_{1}$ diterima. Dengan demikian, dapat dinyatakan bahwa terdapat perbedaan hasil belajar IPA antara kelompok siswa yang mengikuti pembelajaran dengan model Probing-prompting dan kelompok siswa yang mengikuti pembelajaran model konvensional. 


\section{Hasil dan Pembahasan}

Berdasarkan hasil penelitian diatas, diketahui bahwa hasil belajar IPA siswa yang dibelajarkan dengan model pembelajaran probing-prompting berbantuan media video lebih tinggi dibandingkan dengan hasil belajar IPA siswa yang tidak dibelajarkan dengan model pembelajaran probing-prompting berbantuan media video. Adanya perbedaan hasil belajar IPA dari kedua kelompok siswa, menunjukkan bahwa model pembelajaran probingprompting berbantuan media video berpengaruh signifikan terhadap hasil belajar IPA siswa, hal ini terjadi karena pada fase eksplorasi dalam proses pembelajaran yang menerapkan model pembelajaran probing-prompting, guru menghadapkan siswa pada situasi baru dengan memperhatikan video yang mengandung permasalahan di awal pembelajaran. Dalam penayangan vidio, siswa terlihat sangat antusias untuk mengetahui isi dari video tersebut. Setelah mengamati video guru mengajukan beberapa pertanyaan terkait video yang di tayangkan, pada fase ini siswa mulai dituntut untuk menyelesaikan permasalahnnya sendiri. Dengan antusias yang tinggi siswa menggali informasi serta menjawab pertayaanpertanyaan yang dilontarkan oleh guru. Sejalan dengan pendapat Hanson (2006) menyatakan bahwa pada tahap eksplorasi siswa diminta untuk mengeluarkan seluruh pengetahuan awalnya terkait dengan materi yang akan dibahas.

Pada model probing prompting terdapat fase pemahaman konsep, dalam fase ini setelah guru mengajukan beberapa pertanyaan siswa diberikan kesempatan untuk merumuskan jawaban atau melakukan diskusi kecil dengan kelompokknya. Dalam berdiskusi degan kelompok, siswa terlihat lebih aktif saling menanggapi jawaban satu dengan yang lainnya dan mampu membuat sebuah kesimpulan untuk sebuah pertanyaan. Kegiatan pembelajaran pada fase ini memberikan tantangan bagi siswa untuk lebih aktif, berfikir kritis dan bersungguh-sungguh saat mengerjaka soal. Pada fase ini guru menunjuk siswa secara acak untuk menjawab pertanyaan yang sudah di diskusikan dengan kelompok. Dengan ditunjuknya siswa secara acak dapat membuat siswa menjadi lebih sigap dan lebih serius untuk melaksanakan proses pembelajaran di kelas. Dari beberapa siswa yang ditunjuk oleh guru, jika ada siswa yang menjawab kurang tepat, guru akan menampung jawaban-jawaban tersebut dan menunjuk siswa lain untuk memberikan jawaban lainnya. Dengan demikian, siswa mampu untuk befikir secara kritis dan berhati-hati dalam memberikan sebuah jawaban yang telah didiskusikan sebelumnya. Hal tersebut sejalan dengan pendapat Tinio (2003) menyatakan bahwa salah satu keterampilan yang dibutuhkan untuk menghadapi tantangan dimasa yang akan datang adalah keterampilan berpikir tingkat tinggi (higher order thinking) atau sering pula disebut keterampilan berpikir kritis (critical thinking). Keterampilan ini berkaitan dengan kemampuan mengidentifikasi, menganalisis dan memecahkan masalah secara kreatif dan berfikir logis sehingga menghasilkan pertimbangan dan keputusan yang tepat.

Penggunaan media video dalam proses pembelajaran sangat berperan aktif di kelas, hal ini dibuktikan saat video di putar siswa sangat serius untuk menyimak dan mengamati sehingga tidak ada siswa yang bermain atau berbiacara. Hal tersebut berakaitan dengan penemuan Mahadewi (2006) menyatakan bahwa "media video pembelajaran dapat diartikan sebagai media yang digunakan untuk merangsang pikiran, perasaan dan kemauan siswa untuk belajar melalui penayangan ide atau gagasan, pesan dan informasi secara audio visual". Berdasarkan hasil penelitian, menunjukan bahwa pada model pembelajaran Probingprompting berbantuan media video yang diterapkan pada kelompok eksperimen dan pembelajaran konvensional yang diterapkan pada kelompok kontrol dalam penelitian ini menunjukkan adanya pengaruh terhadap hasil belajar IPA siswa. Adanya perbedaan menunjukkan bahwa penggunaan model pembelajaran Probing-prompting memiliki pengaruh yang signifikan terhadap hasil belajar IPA siswa. Perbedaan hasil belajar IPA antara kelompok siswa yang mengikuti pembelajaran dengan model Probing-prompting berbantuan media video dengan kelompok siswa yang mengikuti pembelajaran konvensional disebabkan karena adanya perbedaan perlakuan pada langkah-langkah pembelajaran dan proses penyampaian materi pelajaran. 
Berbeda dengan proses pembelajaran yang berlangsung di kelas kontrol yang tidak menerapkan model pembelarajan Probing-prompting berbantuan media video, siswa cendrung lebih pasif dalam menggali pengetahuannya. Proses pembelajaran ini masih cenderung monoton dan proses pembelajarannya masih didominasi oleh guru. Guru menjelaskan materi pembelajaran, kemudian siswa mendengarkan dan mencatat apa yang ditulis guru dipapan tulis dan terakhir melaksanakan tanya jawab kepada beberapa siswa yang dianggap sudah mengerti. Aktivitas siswa dalam pembelajaran masih cenderung rendah, banyak siswa yang terkadang terlihat membaca buku ketika guru mengarahkan siswa untuk membaca dan menggali informasi terkait materi namun sebenarnya mereka merasa bosan dengan sesekali menunjukkan sikapnya yang melihat keluar dari kaca jendela kelas dan mempehatikan teman sebelahnya serta meletakan telapak tangan dibawah dagunnya. Hal ini menunjukkan siswa kurang tertantang untuk mengikuti proses pembelajaran dan membuat siswa merasa bosan serta tidak nyaman.

Berdasarkan uraian di atas, menunjukkan bahwa dari perbedaan perlakuan menyebabkan terdapat perbedaan hasil belajar IPA antara siswa yang mengikuti pembelajaran dengan model Probing-prompting berbantuan media videodengan siswa yang mengikuti pembelajaran konvensional.

\section{Simpulan dan Saran}

Berdasarkan hasil penelitian dan pembahasan dapat disimpulkan bahwa terdapat perbedaan hasil belajar IPA antara kelompok siswa yang mengikuti pembelajaran dengan model Probing-prompting dan kelompok siswa yang mengikuti pembelajaran model konvensional. Hasil pengujian hipotesis menunjukkan bahwa $t_{\text {hitung }}$ lebih besar dari pada $t_{\text {tabel }}$ yang diuji pada taraf signifikan $5 \%$ dengan $\mathrm{dk}=58$. Dengan demikian, model pembelajaran probing-prompting berbantuan media video berpengaruh terhadap hasil belajar IPA siswa kelas V SD di Gugus V Kecamatan Bangli Tahun Ajaran 2018.

Berdasarkan hasil penelitian yang telah dilakukan, saran yang dapat disampaikan adalah sebagai berikut

1) Bagi Peserta Didik

Disarankan kepada peserta didik, dengan model pembelajaran Probing-prompting berbantuan media video diharapkan siswa dapat meningkatkan kerjasama antar siswa dalam memecahkan suatu permasalahan, sehingga dapat menambah wawasan siswa dalam pengetahuannya agar mampu meningkatkan hasil belajar secara maksimal.

2) Bagi Guru

Disarankan kepada guru, dengan model pembelajaran Probing-prompting berbantuan media video dapat dijadikan salah satu alternatifdalam menggunakan model pembelajaran dan media pembelajaran pada mata pelajaran IPA ataupun pada mata pelajaran lain yang sejenis untuk mempermudah guru dalam menyampaikan materi pelajaran, sehingga siswa cepat memahami dan mengerti materi yang disampaikan.

3) Bagi Kepala Sekolah

Disarankan kepada kepala sekolah, sebagai acuan dalam mengambil kebijakan untuk mengusahakan peningkatan kualitas mutu pendidikan di sekolah dengan memberikan bimbingan kepada guru-guru terutama dalam menggunakan model pembelajaran yang inovatif.

4) Bagi Peneliti Lain

Disarankan kepada peneliti lain agar dapat menggunakan hasil penelitian ini sebagai acuan kepustakaan dalam melakukan penelitian baik dalam variabel yang sama ataupun variabel yang berbeda. 


\section{Daftar Pustaka}

Agung, A. A. G. 2014. Buku Ajar Metodologi Penelitian Pendidikan. Malang: Aditya Media Pubishing.

Amir Nurrizkia. 2017. Pengaruh model pembelajaran probing-prompting terhadap peningkatan berfikir kreatif siswa pada mata pelajaran ipa. Edutcehnologia, Tahun 3, Vol 3 No. 2, Agustus 2017

Ariasih, Sunu, dkk. 2014. "Implementasi Model Pembelajaran Berdasarkan Masalah (Problem Based Instruction) Untuk Meningkatkan Aktivitas dan Hasil Belajar Pkn Siswa Kelas VIII A Semester 2 SMP Negeri 1 Pekutatan Tahun Pelajaran 2013/2014". Tersedia pada http://id.portalgaruda. org/index.php?ref=browse\&mod=viewarticle\&article=304659 (diakses pada tanggal 17 Pebruari 2018).

Beniasih, Suarjana, dkk. 2015. "PengaruhModel Pembelajaran Core Berbantuan Media". Tersedia pada https://ejournal.undiksha.ac.id/index.php/JJPGSD/ article/view/5678. (diakses tanggal 04-01-2018).

Sugiyono, 2008. Metode Penelitian Pendidikan Pendekatan Kuantitati, Kualitatif, dan R\&D. Bandung: Alfabeta.

Susanti Elsa. 2017. Penerapan Model Pembelajaran Probing-Prompting untuk Meningkatkan Kemampuan Berpikir Kritis Matematis Siswa Kelas XI.IPA Man 1 Kota Bengkulu. Jurnal Pendidikan Matematika Raflesia Vol. 2 No. 1 Tahun 2017.

Swarjawa, I. W. E., \& Garminah, N. N. 2013. "Pengaruh Model Pembelajaran ProbingPrompting Terhadap Hasil Belajar Ipa Siswa Kelas V Di Sd Negeri 1 Sebatu". Tersedia pada https://ejournal.undiksha. ac.id/index.php/JJPGSD/article/view/825. (diakses tanggal 04-01-2018).

Tinio, V. L. 2003. ICT In Education. Tersedia pada http://www.apdip.net/publication/iespprimerst/ICTinEducation.pdf. (diakses tanggal 5 Juni 2018). 